\title{
After the Genocide: Psychological Perspectives on Victim, Bystander, and Perpetrator Groups
}

\author{
Johanna Ray Vollhardt* \\ Clark University
}

\section{Michal Bilewicz}

University of Warsaw

Interest in the aftermath of genocide and mass violence has increased in the last few years, and some researchers in various subdisciplines of psychology have begun to address this urgent social issue. Genocide and mass violence continue to influence intergroup relations, conflicts, and policy attitudes. Nevertheless, these topics are still understudied. We introduce this issue by providing a brief overview of the scarce psychological research on the aftermath of genocide among members of former victim, perpetrator, and bystander groups. Although this distinction is too simplistic to explain individual behavior during genocide and its aftermath, we hold on to it as a framework for organizing existing scholarship, and because of the ongoing relevance of these social representations in discourse on this topic. The introduction concludes with an overview of the issue and its organization, including a brief summary of each article.

More than 60 years ago, the United Nations defined genocide as a crime with the intention to destroy, in whole or in part, a national, ethnic, racial, or religious group. Since then, social scientists and historians have contributed significantly to our understanding of genocide: by explaining its roots, describing its dynamics, and discussing its consequences (Fein, 2002; Newman \& Erber, 2002; Staub, 1989). The UN Convention on the Prevention and Punishment of the Crime of Genocide created important tools for punishing perpetrators of genocidal crimes; however, it failed to prevent genocide in the decades thereafter. This is why researchers studying genocide are confronted not only with historical cases such

\footnotetext{
* Correspondence concerning this article should be addressed to Johanna Ray Vollhardt, Department of Psychology, Clark University, 950 Main Street, Worcester, MA 01610 [e-mail: JVollhardt@clarku.edu].
} 
as the Armenian genocide (1915-1917) and the Holocaust during World War II, but also with more recent events such as genocides in Cambodia in the 1970s, Bosnia in 1992-1995, Rwanda in 1994, Darfur, and others.

These recent cases are not the only reason why genocide affects presentday politics and intergroup relations. Historical genocide continues to deeply impact relations between nations and between ethnic groups. For example, the Armenian Genocide Resolution, recently passed by the U.S. House Committee on Foreign Affairs, has led to tensions in American-Turkish relations (McKinnon \& Champion, 2010); and the Katyn Forrest massacre remains the greatest obstacle in Polish-Russian relations, for example, shaping Polish reactions to the recent air disaster in Smolensk (Hunter, 2010). These are only two of many cases in which collective memories of genocide and cultural trauma in general (Alexander, Eyerman, Giesen, Sztompka, \& Smelser, 2004) shape collective identities and political responses of ethnic groups and nations, such as in Israel (Zertal, 2005), Germany (Fulbrook, 1999), or Armenia (Miller, 1999). National identities are built around symbolic commemorations of the past and the narratives of victims as well as of perpetrators. Motivated denial of these memories sometimes serves to restore moral self-image among national groups that were once involved in a genocide as bystanders or perpetrators. Accordingly, such denial was used as a strategy to build national identities in Poland (Steinlauf, 1997), Ukraine (Bartov, 2007), Rwanda (Lemarchand, 2009), and several other countries. At the same time, postgenocidal guilt and forgiveness are equally important for understanding current relations between Germans, Poles, and Jews in Europe; Turks, Armenians, and Azeris in the Caucasus region; Tutsis and Hutus in East Africa; as well as many other groups around the world (Branscombe \& Doosje, 2004). In sum, the impact of historical genocide and mass violence on current social and political issues cannot be underestimated, and it is heavily influenced by psychological reactions among members of former victim, bystander, and perpetrator groups. The aim of this issue is to highlight the role that psychology has to play in explaining intergroup relations, policies, and other social issues shaped by genocidal pasts.

\section{Psychological Research on Genocide}

Genocide as a significant social issue has been tackled by some psychologists. Books such as "The roots of evil: The origins of genocide and other group violence" by Ervin Staub (1989), "The Nazi doctors: Medical killing and the psychology of genocide" by Robert J. Lifton (1986), "Man's search for meaning” by Viktor Frankl (1984), and "The altruistic personality" by Samuel and Pearl Oliner (1988) became key readings in the field of genocide studies, inspiring researchers from several disciplines. The history of genocides, and particularly of the Holocaust, has also stimulated basic social psychological scholarship. In addition to research on obedience (Milgram, 1974), the atrocities committed during World War II have 
also influenced research on intergroup discrimination (Tajfel \& Turner, 1979), dehumanization (Bandura, 1999; Kelman, 1973), delegitimization (Bar-Tal, 1990), moral exclusion (Opotow, 1990), and role-based aggression (Zimbardo, 2007). In several social psychology textbooks, the Holocaust is presented as a result of basic psychological processes of stereotyping, prejudice, conformity, and social identity (e.g., Aronson, Wilson, \& Akert, 2006; Hogg \& Vaughan, 2004; Smith $\&$ Mackie, 2007). Nevertheless, within the field of psychology, genocide in and of itself remains a rather marginal and understudied issue. This is due, at least in part, to the methodological and practical challenges of studying this topic, which does not lend itself easily to experimental research or even to survey research, and which requires integrating historical sources and other materials and methods that are less commonly used in current (mainstream) psychological research.

\section{The Perpetrator-Victim-Bystander Triangle in Research on Genocide}

Most scholars distinguish three major social roles in genocide: perpetrators, bystanders, and victims (Hilberg, 1993). However important these social categories are, they do not provide sufficient information about individual behavior and the multiplicity of roles in times of genocide. These roles are indeed complex and often not as clear-cut as the literature suggests. For example, some members of perpetrator groups perceive themselves as victims (Čehajić \& Brown, 2010), while many victims retaliated against perpetrators in armed struggle (Robins \& Jones, 2009), and many bystanders were also victims (Steinlauf, 1997) while others were violent co-perpetrators (Gross, 2001). In addition, some individuals even occupied all three roles during the same genocide (Bauman, 2000; Perechodnik, 1996). Acknowledging these contradictions and complexities, we continue to use the bystander-perpetrator-victim triangle because most psychological research on genocide and its aftermath addresses these distinct social roles (e.g., Shnabel, Nadler, Ullrich, Dovidio, \& Carmi, 2009; Staub, 1989; Wohl \& Branscombe, 2005), and this framework can be used to organize existing research on this topic. However, it is important to view these distinctions merely as social representations of positions in genocide, and not as explanations for individual behavior of those to whom these roles are ascribed. Several contributions in this issue discuss the fluidity of these roles that needs to be kept in mind when using these seemingly entitative (see Lickel et al., 2000) terms.

\section{Psychological Research on the Aftermath of Genocide}

While some seminal work by psychologists and other social scientists has addressed how genocide evolves (see Newman \& Erber, 2002), in recent years there has been an increasing interest in the aftermath of genocide and mass violence. This has been stimulated by attempts to redress historical injustices and human 
rights abuses, for example, through international war crime tribunals or truth and reconciliation commissions (Barkan, 2000). Psychology can contribute a lot to these discussions, which have practical implications for reconciliation and the prevention of violence. Nevertheless, research in this area is still scarce.

Psychological research on the aftermath of genocide can also be organized along the social roles of previous victim, perpetrator, and bystander groups. This research is located in various subdisciplines of psychology such as social, clinical, and community psychology. In the following, we provide a brief overview of topics that have been studied in this underresearched field, and point to unexplored areas that are addressed in this issue.

\section{Psychological Research among Perpetrator Groups in the Aftermath of Genocide}

Recent research on psychological consequences of genocide among perpetrator groups has focused on positive and negative appraisals of historical victim groups. Descendants of perpetrator groups tend to exonerate their ancestors' misdeeds. When explaining historical crimes, descendants of perpetrator groups often use biased attributions. They perceive historical crimes as caused by situational factors and as unstable, and the perpetrator groups as highly variable (Doosje \& Branscombe, 2003). This bias in explaining historical genocide fits to the pattern of ethnocentric explanations of intergroup behavior, known as the ultimate attribution error (Pettigrew, 1979). Another exonerating strategy among descendants of perpetrator groups is to blame historical victims for their fate (Lerner, 1980). In a similar vein, Imhoff and Banse (2009) showed that reminders of ongoing Jewish suffering after the Holocaust elicit implicit anti-Semitic resentment among contemporary Germans. Thus, prejudice may serve as a strategy to distance oneself from ingroup responsibility for historical genocides. Other distancing strategies are even more direct. For example, Germans who read about atrocities committed by their nation during the Holocaust perceived this period as more remoteand this temporal distancing reduced feelings of collective guilt (Peetz, Gunn, \& Wilson, 2010).

Descendents of perpetrator groups, however, do not always seek to exonerate the crimes committed by their group during genocide. On the individual level, children and grandchildren of Nazi perpetrators have participated in dialogue groups with descendents of Holocaust survivors (Bar-On \& Kassem, 2004), and on the institutional level several German institutions oppose historical denial through educational efforts and exhibitions (Opotow, 2011). Historical gestures by politicians such as the German Chancellor Willy Brandt kneeling in front of the Warsaw Ghetto Memorial in 1970, Polish President Aleksander Kwaśniewski apologizing on behalf of the Polish people in 2001 for the Jedwabne massacre, or British prime minister Tony Blair's statement in 1997 about the Irish Potato Famine are some visible examples of public apologies and expressions of guilt for 
historical harm doing. Although not all apologies are perceived as sincere (Blatz \& Philpot, 2010), they often become milestones in reconciliation after genocide. They are also an important strategy to restore the group's positive self-image as moral (Shnabel et al., 2009) — an image that is severely threatened by a genocidal past.

Positive appraisals of historical victim groups often result from aversive emotions felt by members of the perpetrator group (however, see Imhoff \& Banse, 2009 , for backlash effects). Emotions such as collective guilt, shame, remorse, or regret were found in several studies in response to reminders of crimes committed by ingroup members - sometimes even historically very distant ingroup members (e.g., Brown \& Čehajić, 2008; Doosje, Branscombe, Spears \& Manstead, 1998). Both negative and positive appraisals of victim groups are caused by essentialist ingroup perceptions. Those who believe that they share the same essence with historically distant perpetrators of genocide should feel obliged to compensate for injustice; however, the same essentialist perception also leads to denial of ingroup responsibility. This paradoxical impact of essentialism on collective guilt sheds some light on the psychological limitations of post-genocidal reconciliation (Zagefka, Pehrson, Mole, \& Chan, 2010).

After years of research on perpetrator groups' emotional response to the past (see Wohl, Branscombe, \& Klar, 2006) it is still unclear how common moral reactions to historical atrocities are, and it is still difficult to predict societal reactions to information about historical misdeeds of one's ancestors. The focus on antecedents and consequences of collective guilt constrained researchers' interest in the content of representations of past atrocities. What is still missing in the literature is a detailed analysis of how specific depictions of past crimes among perpetrator groups are linked to emotions and behavioral intentions toward historical victim groups.

\section{Psychological Research among Victim Groups in the Aftermath of Genocide}

Research among victim groups in the aftermath of genocide includes studies with immediate survivors, with descendants of survivors (second or third generation), and with members of the victim group who are at least one generation removed from the events.

Immediate survivors have been studied primarily in clinical psychology. Most of this research has focused on the consequences of trauma. This includes negative outcomes such as posttraumatic stress disorder and revenge (e.g., Field \& Chhim, 2008; for a meta-analysis of studies among Holocaust survivors see Barel, Van IJzendoorn, Sagi-Schwartz, \& Bakermans-Kranenburg, 2010), but also (though less frequently) positive phenomena such as resilience, meaning-making, coping, and posttraumatic growth, which includes altruism (Gasparre, Bosco, \& Bellelli, 2010; Suedfeld, 2000; Vollhardt, 2009). While a lot of this research has been conducted among Holocaust survivors in Israel and in the United States, some 
scarce research also exists on survivors of the Armenian genocide (Kalayjian \& Shahinian, 1998; Kalayjian, Shahinian, Gergerian, \& Saraydarian, 1996), the Cambodian genocide (Field \& Chhim, 2008), and the Guatamalan genocide (Gasparre et al., 2010). As for more recent genocides, there are a number of studies on survivors of the Rwandan genocide (e.g., Kanyangara, Rimé, Philippot, \& Yzerbyt, 2007), and some research among Bosnian survivors (Witmer \& Culver, 2001). Notably, a lot of the existing research is published in psychiatric journals and takes a rather medical than social-constructivist approach to exploring these phenomena.

Clinical research on the aftermath of genocide also includes work on transgenerational trauma and the question whether trauma symptoms are passed down to descendants of survivors. While qualitative and psychoanalytic research has found some evidence to support this idea (e.g., Gruenberg \& Rosental, 2007), meta-analyses of quantitative studies among the second and third generations conclude that there is not sufficient evidence of widespread transmission of trauma symptoms (Sagi-Schwartz, van Ijzendoorn, \& Bakermans-Kranenburg, 2008; van Ijzendoorn, Bakermans-Kranenburg, \& Sagi-Schwartz, 2003).

The scarce social psychological research on the aftermath of genocide and mass violence among victim groups has focused on forgiveness and reconciliation (e.g., Shnabel et al., 2009; Staub, Pearlman, Hagengimana, \& Gubin, 2005) as well as on attributions and construals of the events (Doosje \& Branscombe, 2003; Wohl \& Branscombe, 2005). For example, some research has examined how a more inclusive categorization of the Holocaust (i.e., as a crime against humanity) reduces the level of guilt that is assigned to the perpetrator group and increases willingness for forgiveness among members of the victim group (Wohl \& Branscombe, 2005). Other research has focused on emotional needs among members of the victim group, showing that fulfilling the need for empowerment may increase the willingness for reconciliation among members of victim groups (Shnabel et al., 2009). In addition, several studies illustrate how collective memories and reminders of ingroup victimization through genocide can strengthen ingroup-serving behaviors (Wohl, Branscombe, \& Reysen, 2010) and affect current conflicts by legitimizing what is perceived as defensive violence (Bar-Tal \& Antebi, 1992; Wohl \& Branscombe, 2008). In a way, these phenomena can be viewed as the transmission of trauma and societal trauma symptoms on the collective level (see also Alexander et al., 2004; Volkan, 2001).

Some research has examined interventions that may gradually bring about reconciliation with members of the perpetrator group. These interventions focus on social modeling and understanding of the influences that contribute to mass violence (Paluck, 2009; Staub et al., 2005) and, above all, on contact and dialogue (Albeck, Adwan, \& Bar-On, 2002; Maoz \& Bar-On, 2002). However, these studies also show that these encounters are faced with many challenges, and that backlash is common (e.g., Bar-On \& Kassem, 2004; Bilewicz, 2007). 
In sum, there is only scarce social psychological research among descendants of victim groups in the aftermath of genocide, and most of the existing research in social and in clinical psychology has focused on trauma and destructive consequences. Therefore, more research is needed on positive phenomena after genocide and mass violence, such as altruism and solidarity with other victim groups that may be facilitated through inclusive perceptions of similarity and shared fate (Vollhardt, 2009; see also Suedfeld, 2000).

\section{Psychological Research among Bystander Groups in the Aftermath of Genocide}

Even less research addresses the problem of bystander groups in genocide, their construals of the past, and emotions in response to the events. It is well known that during genocide, bystanders' behaviors allow and even encourage perpetrators to commit atrocities, and that perpetrators' actions significantly affect bystanders' attitudes toward victims (Monroe, 2008; Staub, 1989). Bystanders include not only those who are physically present during genocide, but also distant spectators who did not intervene early enough and thereby allowed genocidal acts to occur (Staub, 2002) - such as Americans during the Holocaust or the international community during the genocide in Darfur. The responsibility of bystanders of genocide, broadly discussed in social sciences (Vetlesen, 2000), has not been extensively studied by social psychologists.

One of the rare studies focusing on bystander descendents who live where the atrocities occurred found that they expressed great interest in the history of genocide in their hometown (Wójcik, Bilewicz, \& Lewicka, 2010). Collective memory of Polish people living in the area of the former Warsaw ghetto focused mainly on the Jewish Holocaust, although the Jewish population and their material heritage had disappeared from the city landscape. The extent to which bystanders' descendents experience collective guilt for their ancestors' passivity depends on the extent to which they are able to take the perspective of historical victims and perpetrators-but this does not affect people who strongly identify with their ingroup (Zebel, Doosje, \& Spears, 2004). Thus, reconciliation between descendants of bystanders and victims of genocide is difficult. Focusing on the past makes the historical bystander role salient (Bilewicz, 2007) and likely threatens the bystander group's moral image (Shnabel et al., 2009).

\section{Overview of this Issue}

This issue aims to fill some of the gaps in this scarce area of research and to bring together perspectives from various subdisciplines in psychology (primarily social and clinical) to better understand the consequences of genocide for current communities and for intergroup relations in different parts of the world. The articles cover a wide range of methods, theoretical approaches, as well as geographical 
and sociopolitical contexts. Drawing on the established historical distinction of social roles during genocide (Hilberg, 1993), this issue is divided into sections on (1) psychological processes among perpetrator groups and (2) psychological processes among victim groups in the aftermath of genocide. The last section deals with (3) interventions and reconciliation between groups that have experienced genocide_-processes that include victim, bystander, and perpetrator perspectives.

\section{Destructive and Constructive Psychological Processes among Perpetrator Groups}

Different forms of moral disengagement and denial of responsibility are dominant reactions to the ingroup's involvement in inhumane actions (Bandura, 1999). In the first section of this issue, two papers explore such destructive processes. Rezarta Bilali (2013) presents social psychological strategies used by Turks to defend their social identity in the aftermath of the Armenian genocide. Bilali (2013) also finds that the level of perceived ingroup responsibility and support for reparations is low. This corroborates analyses presented by Leach, Zeinnedine, and Čehajić-Clancy (2013). In their review of research on collective emotions after genocide and mass violence in the context of colonialism in Africa, Asia, Australia, and the Americas, they find that self-critical reactions to ingroup atrocities are scarce. Feelings of responsibility do not seem to be a dominant reaction among perpetrator groups.

Two other contributions give insight into conditions under which perpetrator groups might come to terms with their burden of historical responsibility, and engage in more constructive responses that contribute to redress and positive intergroup relations. In the context of pogroms committed by Poles during WWII, Kofta and Sławuta (2013) show that focusing on cultural similarities between victims and perpetrators might elicit collective guilt among groups accused of historical crimes. Imhoff, Wohl, and Erb (2013) provide evidence for another guilt-inducing process. In the context of two genocides committed by Germans in the past (of Herero in Namibia and Jews during the Holocaust), they show that awareness of the victims' continuous suffering elicits moral emotions among members of the perpetrator group. These emotions are more pronounced and lead to greater willingness for reparations when the perpetrators' actions are perceived as intentional.

Processes among Victim Groups: Clinical and Social Psychological Perspectives

While the section on processes among perpetrator groups addresses primarily the social psychological perspective, the second section in this special issue, on victim groups, also includes two contributions from a clinical perspective. These articles deal with the more immediate aftermath of genocide, specifically 
with trauma symptoms and healing among survivors. Kaplan (2013) presents a qualitative analysis of interviews with orphans after the Rwandan genocide. From a psychodynamic perspective, she explores their affect regulation as well as factors in their environment that shape their responses and recovery process. Pearlman (2013) argues that in most postgenocide contexts, healing must occur not only on the individual level, but primarily through community-based interventions. She reviews models of community healing after genocide in Bosnia, Rwanda, and other contexts of mass violence and focuses on interventions that provide respect, information, connection, and hope (RICH), all of which are expected to contribute to healing from the massive trauma of genocide.

The two articles that deal with consequences of historical genocide among the victim groups address this issue from a social psychological perspective. Two contributions examine how collective memories of the Holocaust among Israeli and American Jews affect present-day intergroup relations and policy attitudes. Rather than merely focusing on the destructive outcomes of historical trauma, the authors also demonstrate constructive responses that promote peaceful intergroup relations. Klar, Schori-Eyal, and Klar (2013) discuss four lessons that can be drawn from the Holocaust. They show that two of these ("never be a passive victim" and "never forsake your brothers") have fed into the Israel-Palestinian conflict, while two alternative lessons ("never be a passive bystander" and "never be a perpetrator") have motivated humanitarian aid and peace activism in Israel. In an experimental study among Jewish Americans, Vollhardt (2013) shows that inclusive construals of the Holocaust give rise to prosocial attitudes and behavior toward other victims of genocide if both the ingroup's and outgroup's distinct victimization are acknowledged.

\section{Interventions and Policy Implications}

The third section of this issue addresses implications for interventions and policies in the aftermath of genocide and in the service of genocide prevention. Staub (2013) describes how awareness of cultural and psychological precursors of genocide can serve as a starting point for reconciliation between past perpetrators, victims, and bystanders. He reviews a reconciliation radio program in Rwanda, Burundi, and DRC, as well as other interventions to show how experiential understanding facilitates the emergence of peaceful societies after genocide. He argues that this process needs to be strengthened by institutions and positive socialization. Staub's call for active bystandership resonates with a similar call for civil courage expressed by other psychologists writing about genocide prevention (Zimbardo, 2007), who depict heroic helpers as role models for future generations. Bilewicz and Jaworska (2013) show that exposure to heroic helpers can also change relations between grandchildren of bystanders and of victims of genocide. Extending the needs-based model of reconciliation (Shnabel et al., 2009) to bystander groups, 
Bilewicz and Jaworska (2013) discuss how heroic helpers' narratives can restore the group's moral image in encounters between Polish and Israeli students, and how perceived acceptance improves attitudes between these groups.

Overall, these contributions show that the processes of reconciliation between groups affected by historical genocide and prevention of future genocides must be viewed as interconnected. Without reconciliation, victimized groups may choose violent retaliatory actions instead of peaceful solutions to current conflicts, and perpetrator groups may further derogate victim groups and prevent redress. This explains, at least in part, attitudes in recent conflicts in Nagorno Karabakh, DRC, or the Middle East. Thus, understanding psychological processes in the aftermath of genocide can also help us resolve and prevent current political violence and add to our knowledge about these issues (see previous JSI issues edited by Alexander \& Levin, 1998; de Rivera \& Paez, 2007; Finchilescu \& Tredoux, 2010; Muldoon, 2004).

\section{Summary and Conclusion}

In sum, this issue brings together novel research and theorizing on the psychological processes that influence individual and collective healing, reconciliation, and intergroup relations in the aftermath of genocide and other forms of mass violence. The issue showcases the potential psychology has - in conjunction with and informed by other disciplines such as history, political science, sociology, and social work - to contribute to our understanding of these processes, and to shape interventions and policies in the aftermath of mass violence. The issue also shows the unique perspective that psychology can contribute to the interdisciplinary and increasingly popular field of collective memory studies (Olick, Vinitzky-Seroussi, \& Levy, 2011).

This issue aims to integrate a broad range of perspectives on this area of study in terms of the subdisciplines, theoretical frameworks, and geographical and historical contexts involved. This multiplicity of perspectives is necessary in order to even begin to address the complexity of the subject matter. Accordingly, this issue includes social psychological and clinical perspectives and touches on community psychology and developmental issues. The authors draw on a variety of psychological theories and constructs that can be applied to the aftermath of genocide, such as attribution, intergroup emotions, social categorization, contact theory, and trauma theories, and build on existing findings while also contributing severely understudied perspectives such as on bystander groups or on constructive processes in the aftermath of genocide. The methods range from interviews and grounded theory to surveys, experiments, and intervention research. The contexts explored in this issue include the Holocaust, the Rwandan genocide, the Armenian genocide, the Herero genocide, and genocidal violence during colonization in 
the Americas, Asia, Australia, and Africa. Researchers located in Bosnia and Herzegovina, Canada, Germany, Israel, Poland, Sweden, and the United States present studies with samples from Israel, Germany, Poland, Rwanda, Turkey, and the United States and discuss findings from several other contexts.

Even so, this spectrum is still limited, in part due to accessibility of samples. Likewise, authors from Armenia, Cambodia, Rwanda, and other societies that grapple with the experience of genocide and mass violence are missing in this issue. Our hope is nevertheless to document the state of the art in research on the psychological aftermath of genocide and suggest new directions to demonstrate the potential psychology has to contribute to debates and policies around these issues, and to stimulate further debate and research in a variety of contexts.

\section{References}

Albeck, J. H., Adwan, S., \& Bar-On, D. (2002). Dialogue groups: TRT's guidelines for working through intractable conflicts by personal storytelling in encounter groups. Peace and Conflict: Journal of Peace Psychology, 8, 301-322.

Alexander, J. C., Eyerman, R., Giesen, B., Smelser, N. J., \& Sztompka, P. (2004). Cultural trauma and collective identity. Berkeley, CA: University of California Press.

Alexander, M., \& Levin, S. (Eds.). (1998). Understanding and resolving national and international group conflict [Special issue]. Journal of Social Issues, 54(4).

Aronson, E., Wilson, T., \& Akert, R. M. (2006). Social psychology. Harlow: Prentice Hall.

Bandura, A. (1999). Moral disengagement in the perpetration of inhumanities. Personality and Social Psychology Review, 3, 193-209.

Barel, E., Van IJzendoorn, M. H., Sagi-Schwartz, A., \& Bakermans-Kranenburg, M. J. (2010). Surviving the Holocaust: A meta-analysis of the long-term sequelae of a genocide. Psychological Bulletin, 136, 677-698.

Barkan, E. (2000). The guilt of nations: Restitution and negotiating historical injustices. Baltimore, MD: John Hopkins University Press.

Bar-On, D., \& Kassem, F. (2004). Storytelling as a way to work through intractable conflicts: The German-Jewish experience and its relevance to the Palestinian-Israeli context. Journal of Social Issues, 60, 289-306.

Bar-Tal, D. (1990). Causes and consequences of delegitimization: Models of conflict and ethnocentrism. Journal of Social Issues, 46, 65-81.

Bar-Tal, D., \& Antebi, D. (1992). Siege mentality in Israel. International Journal of Intercultural Relations, 16, 251-275.

Bartov, O. (2007). Erased: Vanishing traces of Jewish Galicia in present-day Ukraine. Princeton, NJ: Princeton University Press.

Bauman, Z. (2000). Modernity and the Holocaust. Ithaca, NY: Cornell University Press.

Bilali, R. (2013). National narrative and social psychological influences in the Turkish denial of the Armenian Genocide. Journal of Social Issues, 69, 16-33.

Bilewicz, M. (2007). History as an obstacle: Impact of temporal-based social categorizations on Polish-Jewish intergroup contact. Group Processes \& Intergroup Relations, 10, 551-563.

Bilewicz, M., \& Jaworska, M. (2013). Reconciliation through the righteous: The narratives of heroic helpers as a fulfillment of emotional needs in Polish-Jewish intergroup contact. Journal of Social Issues, 69, 162-179.

Blatz, C. W., \& Philpot, C. (2010). On the outcomes of intergroup apologies. Social and Personality Psychology Compass, 4, 995-1007.

Branscombe, N., \& Doosje, B. (Eds.). (2004). Collective guilt. International perspectives. Cambridge: Cambridge University Press. 
Brown, R., \& Čehajić, S. (2008). Dealing with the past and facing the future: mediators of the effects of collective guilt and shame in Bosnia Herzegovina. European Journal of Social Psychology, $38,669-684$.

Čehajić, S., \& Brown, R. (2010). Silencing the past: Effects of intergroup contact on acknowledgment of ingroup responsibility. Social Psychological and Personality Science, 1, 190-196.

de Rivera, J., \& Paez, D. (Eds.). (2007). Emotional climate, human security, and culture of peace [Special issue]. Journal of Social Issues, 63(2).

Doosje, B., \& Branscombe, N. R. (2003). Attributions for the negative historical actions of a group. European Journal of Social Psychology, 33, 235-248.

Doosje, B., Branscombe, N. R., Spears, R., \& Manstead, A. S. R. (1998). Guilty by association: When one's group has a negative history. Journal of Personality and Social Psychology, 75, 872-886.

Fein, H. (2002). Genocide: A sociological perspective. In A. L. Hinton (Ed.), Genocide: An anthropological reader (pp. 74-90). Oxford: Blackwell.

Field, N. P., \& Chhim, S. (2008). Desire for revenge and attitudes toward the Khmer Rouge tribunal among Cambodians. Journal of Loss and Trauma, 13, 352-372.

Finchilescu, G., \& Tredoux, C. (Eds.). (2010). Intergroup relations in post Apartheid South Africa: Change, and obstacles to change. Journal of Social Issues, 66(2).

Frankl, V. (1984). Man's search for meaning. New York: Pocket/Simon and Shuster.

Fulbrook, M. (1999). German national identity after the Holocaust. Cambridge: Polity Press.

Gasparre, A., Bosco, S., \& Bellelli, G. (2010). Cognitive and social consequences of participation in social rites: Collective coping, social support, and post-traumatic growth in the victims of Guatemala genocide. Revista de Psicología Social, 25, 35-46.

Gross, J. T. (2001). Neighbors: The destruction of the Jewish community in Jedwabne, Poland. Princeton, NJ: Princeton University Press.

Gruenberg, K., \& Rosental, N. (2007). Contaminated generativity: Holocaust survivors and their children in Germany. The American Journal of Psychoanalysis, 67, 82-96.

Hilberg, R. (1993). Perpetrators victims bystanders: Jewish catastrophe 1933-1945. New York, NY: Harper Perennial.

Hogg, M., \& Vaughan, G. (2004). Social psychology. Harlow: Prentice Hall.

Hunter, R. J. (2010). Katyn: Old issues threaten Polish-Russian economic and political relations. European Journal of Social Sciences, 17, 288-297.

Imhoff, R., \& Banse, R. (2009). Ongoing victim suffering increases prejudice: The case of secondary antisemitism. Psychological Science, 20, 1443-1447.

Imhoff, R., Wohl, M. J. A., \& Erb, H.-P. (2013). When the past is far from dead: How ongoing consequences of genocides committed by the ingroup impact collective guilt. Journal of Social Issues, 69, 74-91.

Kalayjian, A., \& Shahinian, S. P. (1998). Recollections of aged Armenian survivors of the Ottoman Turkish Genocide: Resilience through endurance, coping, and life accomplishments. Psychoanalytic Review, 85, 489-516.

Kalayjian, A. S., Shahinian, S. P., Gergerian, E. L., \& Saraydarian, L. (1996). Coping with Ottoman Turkish genocide: An exploration of the experience of Armenian survivors. Journal of Traumatic Stress, 9, 87-97.

Kanyangara, P., Rimé, B., Philippot, P., \& Yzerbyt, V. (2007). Collective rituals, emotional climate, and intergroup perception: Participation in "Gacaca" tribunals and assimilation of the Rwandan genocide. Journal of Social Issues, 63, 387-403.

Kaplan, S. (2013). Child survivors of the 1994 Rwandan Genocide and trauma-related affects. Journal of Social Issues, 69, 92-110.

Kelman, H. (1973). Violence without moral restraint: reflections on the dehumanization. Journal of Social Issues, 29, 25-61.

Klar, Y., Shori-Eyal, N., \& Klar, Y. (2013). The "Never Again" state of Israel: The emergence of the Holocaust as a core feature of Israeli identity and its four incongruent voices. Journal of Social Issues, 69, 125-143.

Kofta, M., \& Sławuta, P. (2013). Thou shall not kill... your brother: Victim-perpetrator cultural closeness and moral disapproval of Polish atrocities against Jews after the Holocaust. Journal of Social Issues, 69, 54-73. 
Leach, C. W., Bou Zeinnedine, F., \& Čehajić-Clancy, S. (2013). Moral immemorial: The rarity of self-criticism for previous generation's genocide or mass violence. Journal of Social Issues, $69,34-53$.

Lemarchand, R. (2009). The dynamics of violence in central Africa. Philadelphia, PA: University of Pennsylvania Press.

Lerner, M. (1980). The belief in a just world. A fundamental delusion. New York, NY: Plenum Press.

Lickel, B., Hamilton, D., Wieczorkowska, G., Lewis, A., Sherman, S. J., \& Uhles, A. N. (2000). Varieties of groups and the perception of group entitativity. Journal of Personality and Social Psychology, 78, 223-246.

Lifton, R. J. (1986). The Nazi doctors: Medical killing and the psychology of genocide. New York, NY: Basic Books.

Maoz, I., \& Bar-On, D. (2002). From working through the Holocaust to current ethnic conflicts: Evaluating the TRT group workshop in Hamburg. Group, 26, 29-48

McKinnon, J. D., \& Champion, M. (2010, March 4). Genocide vote riles Turkey. Wall Street Journal. Retrieved from http://online.wsj.com/article/ SB10001424052748704187204575101981018521028.html

Miller, D. E. (1999). The role of historical memory in interpreting events in the Republic of Armenia. In R. G. Hovannisian (Ed.), Remembrance and denial (pp. 187-200). Detroit, MI: Wayne State University Press.

Milgram, S. (1974). Obedience to authority. New York, NY: Harper \& Row Publishers.

Monroe, K. R. (2008). Cracking the code of genocide: the moral psychology of rescuers, bystanders and Nazis during the Holocaust. Political Psychology, 29, 699-673.

Muldoon, O. (Ed.). (2004). The cost of conflict: Children and the Northern Irish Troubles. Journal of Social Issues, 60(3).

Newman, L. S., \& Erber, R. (2002). Understanding genocide: The social psychology of the Holocaust. New York, NY: Oxford University Press.

Olick, J., Vinitzky-Seroussi, V., \& Levy, D. (Eds.). (2011). The collective memory reader. New York, NY: Oxford University Press.

Oliner, S. P., \& Oliner, P. M. (1988). The altruistic personality: Rescuers of Jews in Nazi Europe. New York, NY: Free Press.

Opotow, S. (1990). Moral exclusion and injustice: an introduction. Journal of Social Issues, 46, 1-20.

Opotow, S. (2011). How this was possible: Interpreting the Holocaust. Journal of Social Issues, 67, 205-224.

Paluck, E. L. (2009). Reducing intergroup prejudice and conflict using the media: A field experiment in Rwanda. Journal of Personality and Social Psychology, 96, 574-587.

Pearlman, L. A. (2013). Restoring self in community: Collective approaches to psychological trauma after genocide. Journal of Social Issues, 69, 111-124.

Peetz, J., Gunn, G., \& Wilson, A. E. (2010). Crimes of the past: Defensive temporal distancing in the face of past in-group wrongdoing. Personality and Social Psychology Bulletin, 36, 598-611.

Perechodnik, C. (1996). Am I a murderer? Testament of a Jewish Ghetto policeman. Boulder, CO: Westview Press.

Pettigrew, T. F. (1979). The ultimate attribution error: Extending Allport's cognitive analysis of prejudice. Personality and Social Psychology Bulletin, 5, 461-476.

Robins, N. A., \& Jones, A. (Eds.). (2009). Genocides by the oppressed: subaltern genocide in theory and practice. Bloomington, IN: Indiana University Press.

Sagi-Schwartz, A., van Ijzendoorn, M. H., \& Bakermans-Kranenburg, M. J. (2008). Does intergenerational transmission of trauma skip a generation? No meta-analytic evidence for tertiary traumatization with third generation of holocaust survivors. Attachment \& Human Development, 10, 105-121

Shnabel, N., Nadler, A., Ullrich, J., Dovidio, J. F., \& Carmi, D. (2009). Promoting reconciliation through the satisfaction of the emotional needs of victimized and perpetrating group members: The needs-based model of reconciliation. Personality and Social Psychology Bulletin, 4, 10211030

Smith, E. R., \& Mackie, D. M. (2007). Social psychology (3rd ed.). Philadelphia, PA: Psychology Press. 
Staub, E. (1989). The roots of evil: The origins of genocide and other group violence. New York, NY: Cambridge University Press.

Staub, E. (2002). The psychology of bystanders, perpetrators, and heroic helpers. In L. Newman \& R. Erber (Eds.), Understanding genocide: The social psychology of the Holocaust (pp. 11-42). New York: Oxford University Press.

Staub, E., Pearlman, L. A., Gubin, A., \& Hagengimana, A. (2005). Healing, forgiveness, and reconciliation in Rwanda: Intervention and experimental evaluation. Journal of Social and Clinical Psychology, 24, 297-334.

Staub, E. (2013). A world without genocide: Prevention, reconciliation, and the creation of peaceful societies. Journal of Social Issues, 69, 180-199.

Steinlauf, M. C. (1997). Bondage to the dead. Syracuse, NY: Syracuse University Press.

Suedfeld, P. (2000). Reverberations of the Holocaust fifty years later: Psychology's contributions to understanding persecution and genocide. Canadian Psychology, 41, 1-9.

Tajfel, H., \& Turner, J. (1979). An integrative theory of intergroup conflict. In W. Austin \& S. Worchel (Eds.), The social psychology of intergroup relations. Monterey, CA: Brooks-Cole.

van Ijzendoorn, M. H., Bakermans-Kranenburg, M. J., \& Sagi-Schwartz, A. (2003). Are children of Holocaust survivors less well-adapted? A meta-analytic investigation of secondary traumatization. Journal of Traumatic Stress, 16, 459-469.

Vetlesen, A. J. (2000). Genocide: A case of the responsibility of the bystander. Journal of Peace Research, 37, 519-532.

Volkan, V. D. (2001). Transgenerational transmissions and chosen traumas: An aspect of large-group identity. Group Analysis, 34, 79-97.

Vollhardt, J. R. (2009). Altruism born of suffering and prosocial behavior following adverse life events: A review and conceptualization. Social Justice Research, 22, 53-97.

Vollhardt, J. R. (2013). "Crime against humanity" or "crime against Jews"? The importance of acknowledgment in construals of the Holocaust for intergroup relations. Journal of Social Issues, 69, 144-161.

Witmer, T., \& Culver, S. M. (2001). Trauma and resilience among Bosnian refugee families: A critical review of the literature. Journal of Social Work Research and Evaluation, 2, 173-187.

Wohl, M. J. A., \& Branscombe, N. R. (2005). Forgiveness and collective guilt assignment to historical perpetrator groups depend on level of social category inclusiveness. Journal of Personality and Social Psychology, 88, 288-303.

Wohl, M. J. A., \& Branscombe, N. R. (2008). Remembering historical victimization: Collective guilt for current ingroup transgressions. Journal of Personality and Social Psychology, 94, 988-1006.

Wohl, M. J. A., Branscombe, N. R., \& Klar, Y. (2006). Collective guilt: Justice-based emotional reactions when one's group has done wrong or been wronged. European Review of Social Psychology, 17, 1-37.

Wohl, M. J. A., Branscombe, N. R., \& Reysen, S. (2010). Perceiving your group's future to be in jeopardy: Extinction threat induces collective angst and the desire to strengthen the ingroup. Personality and Social Psychology Bulletin, 36, 898-910.

Wojcik, A., Bilewicz, M., \& Lewicka, M. (2010). Living on the ashes: Collective representations of Polish-Jewish history among people living in the former Warsaw Ghetto area. Cities, 27, 195-203.

Zagefka, H., Pehrson, S., Mole, R., \& Chan, E. (2010). The effect of essentialism in settings of historic intergroup atrocities. European Journal of Social Psychology, 40, 718-732.

Zebel, S., Doosje, B., \& Spears, R. (2004). It depends on your point of view: Implications of perspectivetaking and national identification for Dutch collective guilt. In N. R. Branscombe \& B. Doosje (Eds.), Collective guilt: International perspectives. New York, NY: Cambridge University Press.

Zertal, I. (2005). Israel's Holocaust and the politics of nationhood. Cambridge: Cambridge University Press.

Zimbardo, P. G. (2007). The Lucifer Effect: Understanding how good people turn evil. New York, NY: Random House. 
JOHANNA RAY VOLLHARDT is currently Assistant Professor of Psychology at Clark University and affiliated with the Strassler Center for Holocaust and Genocide Studies. She received her Ph.D. in Social Psychology from the University of Massachusetts Amherst, with a concentration in the Psychology of Peace and Violence. For her dissertation work she has received the Best Dissertation Award of the International Society of Political Psychology and the Gert Sommer Award for Peace Psychology. Her research focuses on inclusive victim consciousness, prosocial behavior, and intergroup relations in the aftermath of collective violence.

MICHAL BILEWICZ (M.A. 2003, Ph.D. 2007, University of Warsaw) is an Assistant Professor at the Faculty of Psychology, University of Warsaw. He serves as the Director of the Center for Research on Prejudice at the University of Warsaw. He was Fulbright Junior Visiting Researcher at the New School for Social Research in New York and DAAD Post-Doctoral Researcher at Friedrich Schiller University of Jena in Germany. His key research interests are reconciliation processes, linguistic forms of prejudice, anti-Semitism, history-related moral emotions, and dehumanization. 
Copyright of Journal of Social Issues is the property of Wiley-Blackwell and its content may not be copied or emailed to multiple sites or posted to a listserv without the copyright holder's express written permission. However, users may print, download, or email articles for individual use. 